\title{
Skin Squamous Cell Carcinoma or Other Skin Carcinomas pNX TNM Finding v7
}

National Cancer Institute

\section{Source}

National Cancer Institute. Skin Squamous Cell Carcinoma or Other Skin Carcinomas pNX

TNM Finding v7. NCI Thesaurus. Code C88483.

Skin squamous cell carcinoma or other skin carcinomas in which regional lymph nodes

cannot be assessed. (from AJCC 7th Ed.) 